\title{
Does long contact with the soil improve the efficiency of rock phosphate? Results of isotopic studies
}

\author{
JEAN-CLAUDE FARDEAU ${ }^{1}$, CHRISTIAN MOREL ${ }^{2} \&$ MICHEL \\ JAHIEL ${ }^{2}$ \\ 'Commissariat à l'Energie Atomique, Centre d'Etudes Nucléaires de Cadarache, BP 1, \\ 13115 Saint Paul-lez-Durance, France; ${ }^{2}$ Compagnie Française de l'Azote, Service \\ Agronomique, 46 rue J. Dulud, BP 133, 92202 Neuilly-sur-Seine, France
}

Accepted 13 May 1987

Key words: Rock phosphate, diammonium phosphate, ageing, incubation, soil pH, fixing capacity

\begin{abstract}
The effect of incubation on the fate of phosphorus in four phosphatic fertilizers (diammonium phosphate and three rock phosphates) applied to four weakly acid to acid soils was studied. Percent utilisation of fertilizer P by the crop was measured by isotopic labelling and the level and quality of available soil $P$ following addition of fertilizer was measured by the isotopic dilution kinetics method. Percent utilisation of fertilizer P decreased as time of contact between fertilizer and soil increased. The quantity of available soil $\mathrm{P}$ increased immediately after applying fertilizer but then decreased. The efficiency of $\mathbf{P}$ from rock phosphate was not increased by application long before sowing the crop. From practical viewpoint it is important to apply $\mathbf{P}$ fertilizer as near as possible to the time of planting in order to reduce the negative effects of $\mathbf{P}$ fixation by the soil.
\end{abstract}

\section{Introduction}

The interval between application of $\mathrm{P}$ fertilizer and crop uptake of $\mathrm{P}$ may be from a few weeks to four or five months. When heavy dressings are used to build up soil P status of low P soils, the interval may be much increased (a year or more) [27]. There are many reports on the fate of fertilizer $P$ in soils during so-called incubation [32], digestion [10] or ageing [6, 26, 35].

Absolute efficiency of a fertilizer cannot be defined [5]; all we can do is use relative efficiency, i.e. measurement of the availability of one fertilizer relative to another or to soil nutrient. Measurement of this requires that there be a response to fertilizer $\mathrm{P}$ in crop yield or in $\mathrm{P}$ uptake. There may also be a response in available soil $\mathbf{P}$ content as measured by different methods.

In field or greenhouse experiments with water-soluble compounds such as diammonium phosphate or superphosphate, fertilizer $\mathrm{P}$ efficiency measured 
by crop response decreases with time of contact with the soil $[6,8]$. Similarly, $\mathrm{PO}_{4}$ ion concentration in the soil solution [3], $\mathrm{P}$ extracted by chemical reagents [22] or anionic resin [47] and isotopically exchangeable $P$ [38] all decrease with time. These findings support the view that $\mathrm{P}$ fertilizer should be spread just before sowing the crop [21] so that $P$ can be taken up before it has completely reacted with the soil.

On the contrary, it has been recommended that water-insoluble $P$ fertilizers like rock phosphate should be mixed into the soil long before sowing $[11,45]$ on the assumption that acid soils 'digest' rock phosphates making the $\mathrm{P}$ plant-available; If this was so, available $\mathrm{P}$ in a soil-fertilizer system should first increase with time up to a maximum and then decline. Experimental results on this point have been variable. Sometimes rock phosphate has been as good as or somewhat inferior to soluble fertilizer; sometimes it has been without effect. Laboratory measurements of $\mathrm{PO}_{4}$ concentration or of isotopically exchangeable $\mathrm{P}$ have shown that these decrease with time of contact with the soil so that they do not support early spreading and incorporation of rock phosphate.

The aim of our work was to improve understanding of the effect of time of contact between soil and $P$ fertilizer (mainly rock phosphates) and so to propose practical recommendations. Various isotopic determinations were made in the greenhouse and laboratory with four different soils, three insoluble and one water-soluble $\mathbf{P}$ fertilizers

\section{Materials and methods}

Soils.

No P had been applied over at least the past two years to the fields from which the four soils were sampled. Physical and chemical properties of the soils are given in Table 1. By US standards [41] they are high in available $\mathbf{P}$ but by French [25] (2\% citric acid) or UK [12] (extractable P-Olsen) standards, they are low.

\section{P-fertilizers.}

Four P-fertilizers were chosen: diammonium phosphate (DAP), as a watersoluble $P$ source, and three commercial rock phosphates as water insoluble forms. These latter fertilizers consisted of a Tunisian source (Tu), a North Carolina rock phosphate (CNC) and its calcined equivalent (CC). Particle size was $0-63 \mu \mathrm{m}$. Some of their chemical components are given in Table 2. 
Table 1. Soil analyses

\begin{tabular}{lcccc}
\hline Soil & 1 & 2 & 3 & 4 \\
\hline pH $-\mathrm{H}_{2} 0$ & 6.6 & 6.1 & 5.7 & 5.2 \\
Total P (ppm P) & 367 & 851 & 726 & 435 \\
Available Olsen & 19 & 14 & 19 & 17 \\
P (ppm) Dyer & 51 & 38 & 37 & 37 \\
Langmuir K & 0.24 & 0.28 & 0.49 & 1.01 \\
parameters b (ppm P) & 135 & 102 & 125 & 122 \\
Textural class & Silt L. & Loam & Silt L. & Loam \\
Mechanical Clay & 22.8 & 15.8 & 22.2 & 18.9 \\
analysis Silt & 52.8 & 46.6 & 55.8 & 36 \\
(\%) Sand & 24.4 & 22.0 & 37.6 & 45.1 \\
C/N S Sanic carbon \% & 10.7 & 10.5 & 8.4 & 10.5 \\
Organis & 2.1 & 2.4 & 2.6 & 2.6 \\
Exch. K (ppm K) & 180 & 120 & 84 & 85 \\
Exch. Ca (ppm Ca) & 2840 & 1240 & 1000 & 560 \\
\hline
\end{tabular}

The application rate was $66 \mathrm{mg} \mathrm{Pg}^{-1}$ soil corresponding to about

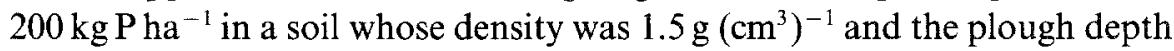
$20 \mathrm{~cm}$.

Unlabelled fertilizers were used for laboratory tests. For greenhouse experiments, the rock phosphates were labelled by neutron activation in a nuclear plant $\left(2.5 .10^{13} \mathrm{n} \mathrm{cm}^{-2} \mathrm{~s}^{-1}\right)$ and the DAP was labelled by laboratory synthesis $[9,18]$. The use of irradiated P-fertilizers has sometimes been criticized [33]. We consider this criticism unjustified for the following reasons: firstly, we have shown $[14,18]$ that the percent of $P$ utilisation by crops is the same for an irradiated labelled or an unlabelled fertilizer. Secondly, the presence of some other radio-isotopes, such ${ }^{45} \mathrm{Ca}$ formed during the irradiation process, is of a great interest for understanding the process of transformation of rock phosphates in soils. Thirdly, in one of the proposed alternative methods [33] used to avoid irradiation, the quantity of soluble $\mathbf{P}$ added as a carrier to the ${ }^{32} \mathrm{PO}_{4}$ ions and added to the soil is of the same order of magnitude as the available quantity already in the soil; such an addition of $\mathrm{P}$ can modify the biological response to a greater extent than the chemical or structural modifications of apatite caused by irradiation.

Table 2. Characteristics of phosphate fertilizer

\begin{tabular}{lcccc}
\hline Fertilizer type & DAP & CNC & Tu & CC \\
\hline Total P (\%) & 20.1 & 13.1 & 12.4 & 13.8 \\
P soluble in 2\% formic acid. (\%) & 20.1 & 9.7 & 7.6 & 3.4 \\
\hline
\end{tabular}


Ageing of phosphate fertilizers in soils.

The ageing of phosphate fertilizers in the soils was achieved by incubation under wet conditions at a temperature above $20^{\circ} \mathrm{C}$. For greenhouse experiments, each labelled fertilizer was mixed with $12 \mathrm{~kg}$ dry soil, sieved at $2 \mathrm{~mm}$, at a rate of $66 \mathrm{mg} \mathrm{m} \mathrm{k}^{-1}$ soil. In each treatment without DAP, $\mathrm{NH}_{4}$, as chloride, was added at $60 \mathrm{ppm}$. After mixing, the soils were put in pots each holiday $1 \mathrm{~kg}$ soil. Six pots of each treatment were wetted to field capacity and maintained in the greenhouse for a month at $20-25^{\circ} \mathrm{C}$; these were considered as the incubated or aged pots. Six other pots were kept under dry conditions and were considered as being non incubated. There were 240 pots altogether: 4 soils, 2 ageing periods ( 0 and 1 month), 5 fertilizer types (one control and 4 fertilizers) and 6 repetitions for each treatment.

For laboratory analysis, unlabelled fertilizer was mixed with dry soils at the same rate. Part of the mixture was wetted to field capacity and incubated in plastic vials: the other part was maintained under dry conditions as unincubated soil.

Analytical methods for availability of fertilizer $P$.

Fertilizers $\mathbf{P}$ availability was measured either by pot experiments or laboratory tests.

(a) Pot experiments and crop response. After one month of incubation, all pots were sown simultaneously with one gram of Lolium perenne seed. Seven days after sowing and at each cutting, $50 \mathrm{ppm} \mathrm{N}$ as $\mathrm{KNO}_{3}$ were added to each pot. Three cuts were taken at one month intervals. Shoots were analysed for dry matter content and for radioactive and stable phosphorus contents.

Two types of calculations were used for the analysis of these measurements:

- Percent of $P$ utilisation of the various fertilizers. If $R$ is the total ${ }^{32} \mathbf{P}$ in the fertilizer and $\mathrm{r}$ and ${ }^{32} \mathrm{P}$ content of crops, the percent of $\mathrm{P}$ utilisation (PU) is calculated as:

$$
\mathrm{PU} \%=\frac{\mathrm{r}}{\mathrm{R}} * 100
$$

- Phosphorus derived from fertilizer (Pdff \%). The expression first used in a previous experiment with ${ }^{32} \mathrm{P}$ labelled fertilizers [23], designates the proportion of the nutrient in plants that is derived from fertilizer. The major interest of this value is that it is more independent of the cultural conditions 
than the PU \%. It can be calculated by two equivalent formulae:

$$
\mathrm{Pdff} \%=\frac{\text { Specific radioacitivity of } \mathrm{P} \text { in crop }}{\text { Specific radioactivity of } \mathrm{P} \text { in fertilizer }} \cdot 100
$$

or

$$
\text { Pdff } \%=\frac{\text { Percent of } \mathrm{P} \text { utilisation } \cdot \text { Rate of application }}{\text { Total } \mathrm{P} \text { in crop }}
$$

(b) Laboratory tests. Isotopic dilution kinetics. Phosphorus extracted by a chemical procedure is called 'available P'. In fact, correlation between 'available' $\mathrm{P}$ and the phosphorus taken up by crops can only be obtained under standard conditions; there is no proof that the phosphorus extracted from soil by a chemical is the same as that taken up by plants. We therefore prefer to use a method which can provide information on truly available phosphate ions. The only way this type of information can be obtained is by using isotopic dilution kinetics. It has been established that the available pool of phosphorus is the isotopically exchangeable pool of $\mathrm{PO}_{4}[15,17]$ and this determination is made without addition of any chemical mobilizing or immobilizing the soil phosphate [37]. Isotopic dilution kinetics were determined as follows: $10 \mathrm{~g}$ soil were mixed in $99 \mathrm{ml}$ water over night to obtain a steady-state soil-solution system. One $\mathrm{ml}$ of ${ }^{32} \mathrm{P}$ as carrier-free ${ }^{32} \mathrm{PO}_{4}$ ions was then injected at time zero into the system and well mixed with a magnetic stirrer (200 revolutions per minute). At time $t=1,10$ and 100 minutes, about $100 \mathrm{ml}$ of the labelled mixture were sampled with a syringe and the solution immediately separated from soil using a millipore filter $(0.2 \mu \mathrm{m}$ pore size). Radioactivity, $\mathrm{r}$, remaining in the solution at each time, $t$, was measured and the quantity of phosphate ions in solution, $M_{1}$, which remained constant during all the experiment since the soil-solution system was in a steady-state and the ${ }^{32} \mathrm{P}$ added without carrier, was determined after the last sampling of the isotopic exchange. It has been previously established $[15,17]$ that the evolution of $r$ with time, during the interval $0.5 \mathrm{mn}-3$ months, can be described as:

$$
\mathrm{r}=\mathrm{r}_{1} \cdot \mathrm{t}^{-\mathrm{n}}
$$

$r_{1}$ is the radioactivity remaining in solution at the time $t=1 \mathrm{mn}$ and $\mathrm{n}$ an empirical parameter varying from 0 to 0.5 depending on soils and treatments 
in a given soil. In such an experiment, the isotopically exchangeable soil phosphorus, E, can be calculate by the formula:

$$
\frac{\mathrm{r}}{\mathrm{M}_{1}}=\frac{\mathrm{R}}{\mathrm{E}}
$$

assuming that, at any time, the specific radioactivity of phosphate ions in the soil-solution equals the specific radioactivity of all the phosphate ions present in an exchangeable form in the soil-solution system. From equation (4), the latter relationship becomes:

$$
\mathrm{E}=\frac{\mathrm{M}_{1} \cdot \mathrm{R}}{\mathrm{r}_{1}} \cdot \mathrm{t}^{\mathrm{n}}=\mathrm{E}_{1} \cdot \mathrm{t}^{\mathrm{n}}
$$

From this equation it can be seen that: i) exchangeable soil phosphorus increases with the exchange time. It means that the choice of $24 \mathrm{~h} \mathrm{[31],} 3 \mathrm{~d}$ [44] or $21 \mathrm{~d}$ [25] retained by different authors is not really justified. ii) a clear knowledge of the exchangeable soil phosphorus depends, at least, on the determination of $r_{1} / R, M_{1}$ and $n$.

In addition, using a double isotopic dilution method, we also measured a quantity, $\mathrm{M}_{2}$, of phosphate ions which are soil-linked but as accessible for nutrition as the quanitity $M_{1}$ present in solution.

This determination was carried out as follows: an isotopic dilution experiment was performed as previously, but without sampling in a $250 \mathrm{ml}$ centrifuge tube. After an isotopic exchange period of $100 \mathrm{mn}$ or more, this tube was centrifuged at $20,000 \mathrm{~g}$ or more, the supernatant discarded, and its radioactivity content, $\mathrm{r}_{100}$ measured. This supernatant was immediately replaced by a similar supernatant obtained in a similar manner (same soil, soil-solution ratio and agitation time) as previously but without ${ }^{32} \mathrm{PO}_{4}$ labelling. A new instantaneous isotopic exchange took place between the labelled phosphate ions of the soil and the unlabelled phosphate ions of the new solution. The radioactivity, $\mathrm{r}^{\prime}{ }_{100}$ returning into the solution was immediately measured after millipore filtration. It has been previously demonstrated [17] that the quantity $M_{2}$ is given by:

$$
\mathbf{M}_{2}=\mathrm{M}_{1} \cdot \frac{\mathrm{r}_{100}^{\prime}}{\mathrm{r}_{100}-\mathrm{r}_{100}^{\prime}}
$$

A more complete picture of the available soil $\mathrm{P}$ therefore requires the knowledge of: 
- $\mathrm{M}_{1}$, the phosphate ion concentration in the soil-solution which is the intensity factor described by White and Beckett [49].

- $\mathrm{r}_{1} / \mathrm{R}$ and $\mathrm{n}$ which are related to the fixing capacity of the soil for phosphate ions.

- $\mathbf{M}_{1}+\mathrm{M}_{2}$, the quantity of phosphate ions of the soil-solution system which is, in any circumstances, the source of $\mathrm{P}$ for crop nutrition and corresponds to the quantity factor [49].

\section{Results and discussion}

Crop response

Crop data of the three cuttings are summed together: dry matter yield and $P$ uptake are given in Table 3 and the percentage of $P$ utilisation of the various fertilizers in Table 4. Statistical analysis was confined to the different treatments for a given soil; soils were not compared.

(a) Results without ageing. Only DAP significantly increased dry matter production in three out of four soil. This results seem to contrast with much published data where all fertilizers used, including rock phosphates, had positive effects in soils said to be poor in available $P$. Two main reasons can explain this apparent discrepancy:

- Firstly, most of the published data on the positive effect of rock phosphates were obtained in soils poor in available phosphorus. While the soils used in the experiments described here are poor in available $\mathrm{P}$ according to the French methods (Dyer and/or Joret-Hebert) and their associated standards [25], they appear medium or high in available $\mathrm{P}$ according to Olsen method [4].

- Secondly, the values of the percent of $P$ utilisation of the various fertilizers, which is varied from 0.5 to $16.8 \%$ (Table 4) contribute to the explanation of the differences observed between water-soluble and waterinsoluble forms of $P$ fertilizers. It can be seen that: i)fertilizer $P$ given in water soluble form was taken up to a greater extent than when given in a water insoluble form. ii)the rating of the fertilizers was the same for all the soils: $\mathrm{DAP}>\mathrm{CNC}>\mathrm{Tu}>\mathrm{CC}$, but the rate of $\mathrm{P}$ uptake depended on soil physical and chemical properties.

These results also stimulate some other comments. In soil 1 , where $\mathrm{pH}$ water was 6.6 , less than $2 \%$ of the phosphorus applied as rock phosphate was taken up in three months. This additional result confirms those previously observed: $\mathrm{pH} 6.1$ seems to be the upper soils limit for significant 


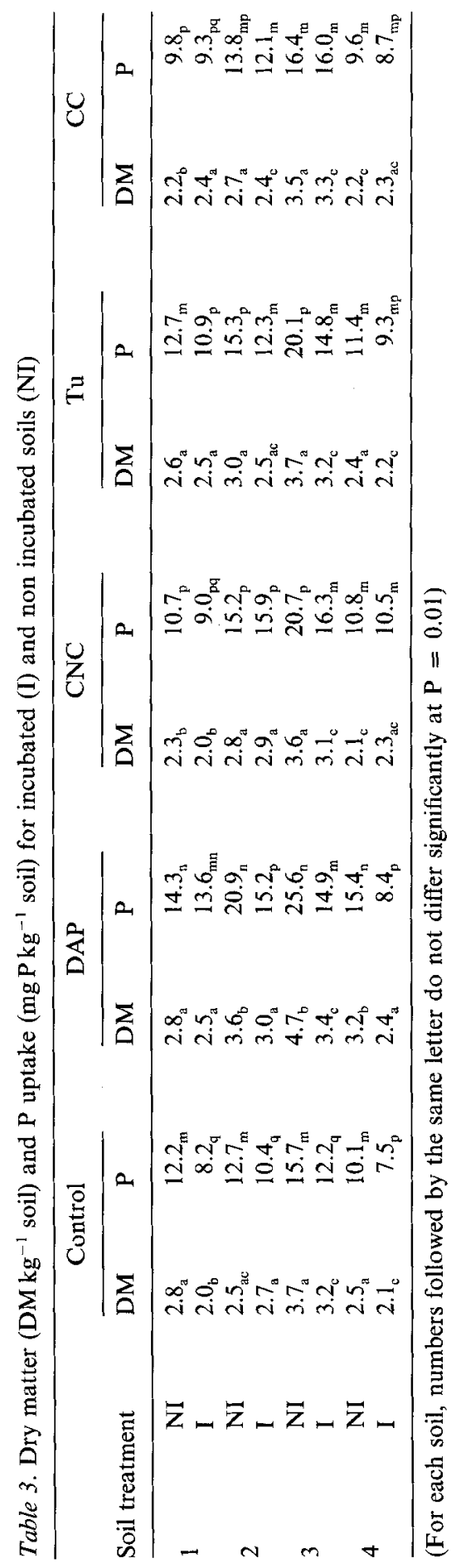


Table 4. Percent of P utilization of the fertilizer by crop, P.U.\% for incubated (I) and non incubated soils (NI)

\begin{tabular}{llrlll}
\hline \multicolumn{2}{c}{ Soil treatment } & DAP & CNC & TU & CC \\
\hline 1 & NI & $8.2_{\mathrm{a}}$ & $2.0_{\mathrm{b}}$ & $1.0_{\mathrm{c}}$ & $0.5_{\mathrm{d}}$ \\
& $\mathrm{I}$ & $8.0_{\mathrm{a}}$ & $1.6_{\mathrm{e}}$ & $1.1_{\mathrm{c}}$ & $0.6_{\mathrm{d}}$ \\
2 & $\mathrm{NI}$ & $7.5_{\mathrm{a}}$ & $3.5_{\mathrm{b}}$ & $1.3_{\mathrm{c}}$ & $1.1_{\mathrm{d}}$ \\
& $\mathrm{I}$ & $7.9_{\mathrm{a}}$ & $3.3_{\mathrm{b}}$ & $1.3_{\mathrm{c}}$ & $0.9_{\mathrm{d}}$ \\
3 & $\mathrm{NI}$ & $16.8_{\mathrm{a}}$ & $8.4_{\mathrm{b}}$ & $6.2_{\mathrm{c}}$ & $3.1_{\mathrm{d}}$ \\
& $\mathrm{I}$ & $6.2_{\mathrm{c}}$ & $6.6_{\mathrm{c}}$ & $3.9_{\mathrm{c}}$ & $3.3_{\mathrm{d}}$ \\
& $\mathrm{I}$ & $10.8_{\mathrm{a}}$ & $5 . \mathrm{b}_{\mathrm{b}}$ & $3.7_{\mathrm{c}}$ & $1.5_{\mathrm{d}}$ \\
& $\mathrm{NI}$ & $3.9_{\mathrm{c}}$ & $5.2_{\mathrm{b}}$ & $2.9_{\mathrm{e}}$ & $1.5_{\mathrm{d}}$ \\
\hline
\end{tabular}

(For each soil, numbers followed by the same letter do not differ significantly, $\mathrm{P}=0.01$ )

utilisation of rock phosphate independent of geographical and geological origins.

The Carolina and Tunisian rock phosphate whose solubilities in formic acid at $2 \%$ was of the same order of magnitude, were more efficiently absorbed by crops than the calcined Carolina rock phosphates whose formic solubility was lower. This result agrees with others published recently [32, 33 ] concerning the correlation between solubility in formic acid and availability of rock phosphates. It can also be concluded, in agreement with studies on Gafsa rock phosphate [34], that calcination of apatite to destroy organic matter, an industrial process for phosphoric acid production, has a negative effect on its agronomic efficiency.

(b) Results with ageing of fertilizers in soils. i) After the ageing period there was no significant effect of fertilizers on dry matter yield except for soil 1 and 4 with DAP. ii) The rating for the percent $P$ utilisation of the fertilizers remained the same in all soils as without ageing. iii) In neutral soils, $\mathrm{pH}=6.6$, the percentage of $\mathrm{P}$ utilisation of rock phosphate remained very low. In the two weakly acid soils, the percent $\mathrm{P}$ utilisation for the water soluble form and for the better rock phosphate (CNC) were of the same order of magnitude. Compared with the data obtained without ageing, these results can be explained either by a decrease in the availability of the water soluble form, or by an increase in the availability of rock phosphate. At the same time, soil incubation in wet conditions decreased dry matter yield and phosphorus uptake even for control soils which can be explained by an alteration of the physical properties of soils such as soil packing, which can greatly reduce root growth and development [9]. The choice between the two hypothesis can be made on the basis of the Pdff\% values (Table 5). The decrease in the Pdff\% values during the wet conditions, as compared with dry conditions, of the water soluble form showed the decay in the efficiency 
Table 5. Phosphorus derived from fertilizer, Pdff \% in incubated (I) and non incubated soils (NI)

\begin{tabular}{rlllll}
\hline \multicolumn{2}{c}{ Soil treatment } & DAP & CNC & TU & CC \\
\hline \multirow{2}{*}{1} & NI & $37.8_{\mathrm{a}}$ & $12.3_{\mathrm{b}}$ & $5.2_{\mathrm{c}}$ & $3.4_{\mathrm{d}}$ \\
& I & $38.8_{\mathrm{a}}$ & $11.7_{\mathrm{b}}$ & $6.6_{\mathrm{c}}$ & $4.2_{\mathrm{d}}$ \\
2 & NI & $33.6_{\mathrm{a}}$ & $15.2_{\mathrm{b}}$ & $5.6_{\mathrm{c}}$ & $5.3_{\mathrm{c}}$ \\
& I & $34.3_{\mathrm{a}}$ & $13.6_{\mathrm{b}}$ & $6.9_{\mathrm{d}}$ & $4.9_{\mathrm{c}}$ \\
3 & NI & $43.3_{\mathrm{a}}$ & $26.8_{\mathrm{b}}$ & $20.3_{\mathrm{c}}$ & $12.5_{\mathrm{d}}$ \\
& I & $27.5_{\mathrm{b}}$ & $26.7_{\mathrm{b}}$ & $17.4_{\mathrm{e}}$ & $13.6_{\mathrm{d}}$ \\
& I & $46.2_{\mathrm{a}}$ & $31.2_{\mathrm{b}}$ & $21.4_{\mathrm{c}}$ & $10.3_{\mathrm{d}}$ \\
& NI & $30.6_{\mathrm{b}}$ & $32.7_{\mathrm{b}}$ & $20.5_{\mathrm{c}}$ & $11.3_{\mathrm{d}}$ \\
\hline
\end{tabular}

(For each soil, numbers followed by the same letter do not significantly differ $P=0.01$ )

of this form. During the same period, the Pdff\% values for rock phosphates were not increased; it can therefore be concluded that the efficiency of rock phosphates was not increased by soil digestion, even in the acid soils. The similar percentage $P$ utilisation for DAP and rock phosphate after one month of wet incubation was due only to a decrease in the efficiency of the DAP and rock phosphate after one month of wet incubation was due only to a decrease in the efficiency of the DAP. The same results also show the very weak contribution of rock phosphate to plant nutrition in soils with a pH above 6.1 (soils 1 and 2).

\section{Soil phosphorus analysis after P fertilizer addition}

(a) Results without ageing period (Table 6 and 7).. In comparison with the control soil, addition of DAP significantly increased $\mathbf{M}_{1}, \mathbf{M}_{1}+\mathbf{M}_{2}$ and $\mathbf{r}_{1} / \mathbf{R}$ but none of the rock phosphates really modified these parameters. Thus, in these soils and in agreement with other data $[16,18]$, water-soluble forms of fertilizers can increase the quantity and availability of the available pool of soil phosphorus.

(b) Results with ageing (Table 6 and 7).. After the incubation period DAP increased the various parameters in only three out of four soils. There were no significant differences between control soils and soils given rock phosphates. The labile pool of $\mathrm{P}$ and its availability, determined by isotopic dilution kinetics method, were therefore not increased by digestion of the rock phosphates in the soils.

From the comparison of the data observed with and without incubation it can be deduced that:

- Incubation decreased the efficiency of DAP for all the soils $\mathbf{M}_{1}$, $M_{1}+M_{2}$ and $r_{1} / R$ being decreased. This was obvious in soil 4 , where all the 


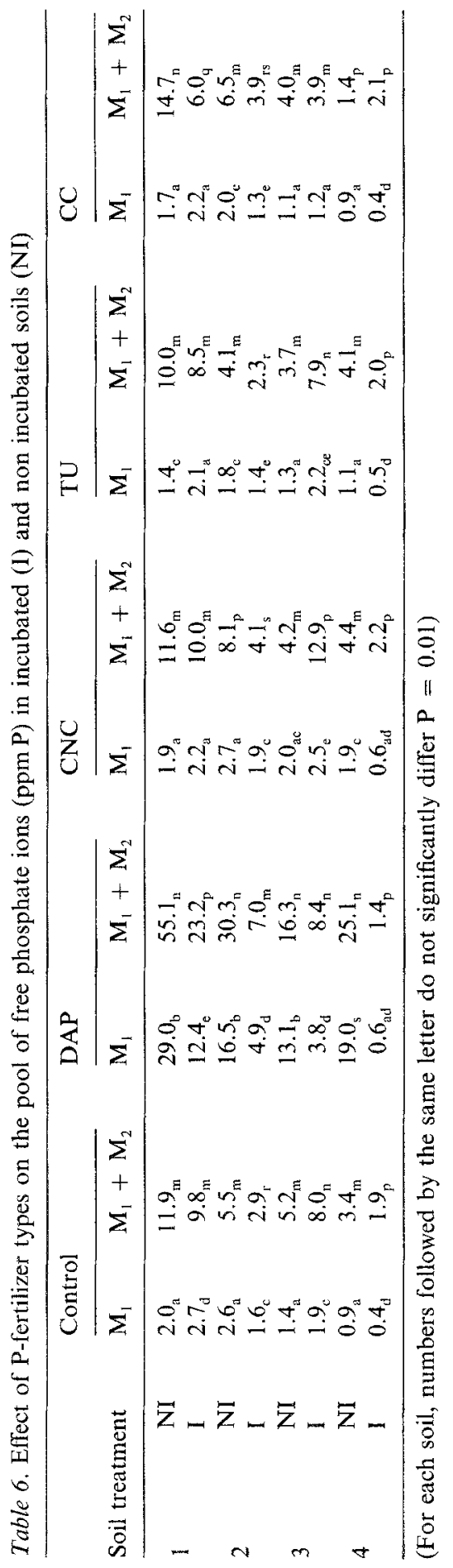




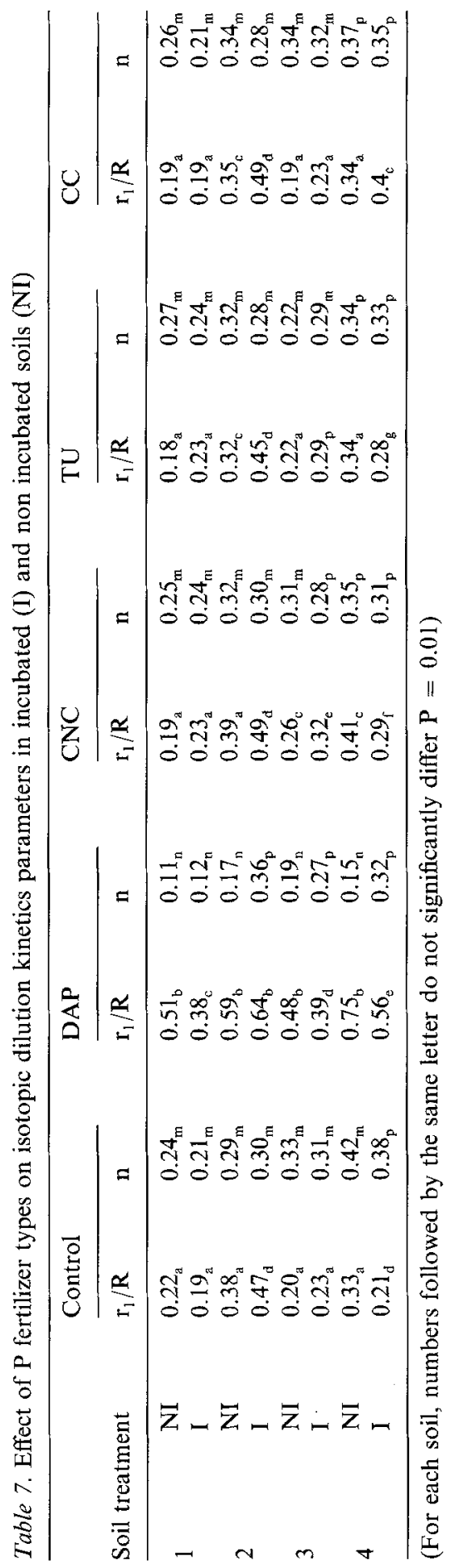


treatments gave identical results. In this soil, the most acidic, neither the water-soluble nore the insolube $\mathrm{P}$ forms of fertilizers increased the available soil phosphorus when applied at agronomic rates. This can easily explained, for water-soluble $\mathrm{P}$ forms, by the quick reactions of phosphate ions with with aluminium and iron compounds [43] which are always present in acid soils.

- Incubation induced some modifications in soil fertility even in control soils.

\section{Comparison of crop response and soil analysis}

Soil fertility was slightly modified during an incubation period under wet conditions for all the control soils; this result was observed both in pot experiments (Table 3) and from analyses (Table 6 and 7). It could be explained by changes in the structural and/or chemical properties of the soils but not by an earlier input of $\mathrm{P}$ fertilizer since these soils were taken from unfertilized fields. Structural modifications can affect root development, this being increased or decreased, for example, by soil packing [9]. Chemical changes would also affect $P$ fertility: observations in grassland ecosystems have indicated a seasonal increase (or decrease) in available $\mathrm{P}$, as estimated by the Olsen method [29]. So it may be that incubation in wet and warm conditions, can modify chemical P fertility of the soil as may change between winter and spring or between spring and summer according to the area. It is known that during incubation, transformations by mineralization or reorganisation of organic compounds occur [30]; the newly formed products can affect, as can many organic compounds, the phosphorus fixing capacity of soils $[19,24]$. Moreover, the nitrification process with occurs in many circumstances and produces protons [20], can either dissolve phosphates [40] and increase $\mathrm{P}$ fertility or, in more acid soils, dissolve $\mathrm{Al}$ and decrease $\mathrm{P}$ solubility and thus $\mathrm{P}$ chemical fertility. In the present experiments soil analysis revealed a decrease in soil $P$ fertility in three soils $(1,2$ and 4$)$ and an increase in one soil (3) (Table 6: values of $M_{1}$ and $M_{1}+M_{2}$ ). It can be assumed that organisation dominated in soils 1,2 and 4 and that mineralization of organic $P$ occurred in soil 3 . The quantities appearing (soil 3) and disappearing (soil 2 and 4) in the pool of the free phosphate ions during incubation were about 2 or $3 \mathrm{ppmP}$. After one month incubation, the input of $66 \mathrm{ppmP}$ of water-insoluble $\mathrm{P}$ form (about $200 \mathrm{~kg} \mathrm{P}^{-1}$ ) increased the $\mathrm{M}_{1}+\mathrm{M}_{2}$ phosphate ions pool from 0 (soils 3 and 4) to $13 \mathrm{ppm} P$ (soil 1), so the 2 or $3 \mathrm{ppm} \mathrm{P}$ correspond to a fertilization of about $50 \mathrm{~kg} \mathrm{Pha}^{-1}$. This result is sufficient to explain why one year we can observe a crop response to $\mathbf{P}$ fertilization in a given field, while in a following year there is no response. 
Incubation, i.e. an increase in contact time between soil and fertilizer under wet conditions, did not increase fertilizer availability even for rock phosphates which disagrees with generally held ideas: phosphorus in plants derived from fertilizer decreased with incubation time and soil $\mathbf{P}$ fertility was not increased.

Many authors have concluded from field [13] or pot [28] experiments that rock phosphate and water-soluble phosphate forms are similarly efficient for dry matter production. The yields obtained in the present study with soil 4 (Table 3, 4 and 5) using DAP and CNC, the better rock phosphate, provide good examples to discuss such reported equal efficiency. It is true that, after incubation, dry matter yields with DAP and CNC were of the same order of magnitude and that soil analysis, namely for phosphate ion concentration in the soil solution (Table 6) explained these results. However without incubation dry matter yields obtained with these two fertilizers differed significantly, as did phosphate ion concentration in the soil solution. It can therefore be said that the efficiency of the water-soluble form was decreased following reactions with soils components.

In general, it can be concluded that the efficiency for crop production of $\mathbf{P}$ fertilizers greatly depends on their contact time with soils and that all $\mathbf{P}$ fertilizers lead, with time, to the same level of $P$ fertility, which in turn does not differ from that of the native soil [36]. The speed of the return to the equilibrium state depends on the nature of the soil components. From one Rothamsted experiment [48], it can be concluded that the residual effect of $P$ fertilizers on crop yield can be observed after 50 years or more, but in the majority of field experiments phosphate applications do not remain effective for more than 2 or 3 years and further applications are therefore needed [2]. These last comments and our observations, are in accordance with data concerning the residual effect of fertilizers determined by the decrease, with time, of the available soil phosphorus estimated by the L-value method [36]. A half-life of $P$ fertilizers was defined from these data and varied with soils. However, as the decrease in phosphate ion concentration is most probably fitted to a power function [3] rather to an exponential function, it would be more accurate to calculate and mean sojourn time rather than an half-life which is related only to the exponential function [46]. Finally, there is an apparent contradiction between soil analysis and crop $\mathrm{P}$ response namely for soil 4 in the case of an addition of rock phosphate as $\mathrm{CNC}$, particularly in the absence of incubation, but also with an incubation period. In this soil CNC increased $\mathrm{P}$ uptake but did not increase available soil phosphorus. The increase of $\mathrm{P}$ uptake is explained by the value of the percentage of $\mathrm{P}$ utilization (Table 4) which is $5.2 \%$, i.e. $66 \times 0.052=3.4 \mathrm{mg} \mathrm{P} \mathrm{kg}^{-1}$ soil. An explanation of these results could be: unlike the water-soluble form 
which quickly reacts with soil components and becomes unavailable like the major part of the soil $P$, rock phosphates remain in their native form in these weakly acid soils and their phosphate ions do not react with soils. They consequently keep a low, but constant, efficiency, nearly $1 \%$ of $\mathrm{P}$ utilization at each cutting in the present study and this very low effect does not give significant differences for isotopic dilution parameters.

\section{Conclusions}

(i) The immediate effect of a $\mathbf{P}$ fertilizer on dry matter yield and $\mathrm{P}$ uptake, estimated in pot experiments with labelled fertilizers, depends on both the fertilizer type and on the contact period between soil and fertilizer. The availabilities of both water soluble and insoluble forms decrease with increased contact time between soil and fertilizer. The rate of this decrease is higher for soluble $\mathrm{P}$ than for insoluble $\mathrm{P}$ but it also depends on the fixing capacity of the soil. In agricultural practice, therefore the contact period between soil and fertilizer should be as short as possible, even for rock phosphate.

(ii) The residual effect of $\mathrm{P}$ fertilizer, i.e. its ability to increase either the quantity of the available $P$ or to increase its availability, depends also on the fertilizer type and on the contact time with soil, as is shown by determination of the isotopic dilution kinetic parameters. As for the pot experiment, the available quantity decreases with time of contact both for soluble and insoluble forms. These soils analyses confirm results from pot experiments that contact between soil and $\mathrm{P}$ fertilizer should be as short as possible.

In order to reduce losses of phosphate fertilizers into unavailable forms, farmers should attempt to supply phosphorus when the plants need it.

\section{References}

1. Amberger A (1978) Experiences with soft rock phosphates for direct fertilizer application. In: seminar on phosphate rock for direct application, pp. 349-366. IFDC, Muscle Shoals, Alabama

2. Barrow NJ (1980) Evaluation and utilisation of residual phosphorus in soils. In: the role of phosphorus in Agriculture, pp. 333-360. Madison, Wisc: American Society of Agronomy

3. Barrow NJ and Shaw TC (1975) The slow reaction between soils and anions. The effects of time and temperature on the decrease in isotopically exchangeable phosphate. Soil Sci. 119- $190-196$

4. Bingham FT (1962) Chemical tests for available phosphorus. Soil Sci 94: 87-95 
5. Black CA and Scott CO (1956) Fertilizer evaluation. I. Fundamental principles. Soil Sci Soc Am Proc 20: 176-179

6. Blanchet R, Bosc M, Gelfi N and Hilaire A (1971) Vieillissement d'engrais phosphatés dans le sol et conduite de la fertilisation. Ann Agro 22: 687-703

7. Blanchet $R$, Bose $M$ and Maertens C (1978) Influence de l'état hydrique du sol sur l'alimentation phosphorique des plantes. Phosphore et Agriculture 72: 1-11

8. Bolland MDA and Bowden JW (1984) The initial and residual value for subterranean clover of phosphorus from crandallite rock phosphate, apatite rock phosphate and superphosphate. Fert. Res. 5: 295-307

9. Boniface R, Fardeau JC, Guiraud G and Trocme S (1979) Etude à l'aide des traceurs du prélèvement par du blé d' hiver de phosphore et d'azote appliqués en couverture. Agrochimica 23: $165-178$

10. Cabala-Rosand P and Wild A (1982) Direct use of low grade phosphate rock from Brazil as fertilizer. I. Effect of reaction time in soil. Plant and Soil 65: 351-362

11. Cooke GW (1967) The control of soil fertility, 1st edn. London: Crosby Lockwood \& son ltd

12. Cooke (1978) Experimental work in the United Kingdom on the agricultural value of rock phosphate. In: Seminar on Phosphate Rock for Direct Application, pp 304-324. IFDC, Muscle Shoal, Alabama

13. Davies GR (1984) Comparison of water insoluble phosphate fertilizers with superphosphate- a review. J Sci Food Agric 35: 265-271

14. Fardeau JC and Guiraud G (1972) Détermination simultanée des valeurs $A$ et $L$ du phosphore d'un sol à l'aide du ${ }^{32} \mathrm{P}$ et $\mathrm{du}{ }^{33} \mathrm{P}$. In: Symposium Isotopes and Radiation in soil-plant relationships including forestry, pp. 499-506. AIEA SM-151/20, Vienne

15. Fardeau JC and Jappe J (1976) Nouvelle méthode de détermination du phosphore assimilable du sol par les plantes: extrapolation des cinétiques de dilution isotopique. CR Acad Sci Paris, T 282, série D, 1137-1140

16. Fardeau JC and Jappe J (1978) Analyse par dilution isotopique de la fertilité et de la fertilisation phosphorique de quelques sols du Quebec. Can J Soil Sci 58: 251-258

17. Fardeau JC (1981) Cinétique de dilution isotopique et phosphore assimilable des sols, 198 p. Thèse Doctorat d'Etat, Paris

18. Fardeau JC, Gjermani A, Malja S and Migadel F (1983) Efficacité d'un phosphate à faible teneur dans quelques sols d'Albanie: mesure au moyen de ${ }^{32} \mathrm{P}$. In: Actes du $3^{3}$ ème Congrès International sur les composés phosphorés, pp. 519-532. IMPHOS, Casablanca, Maroc

19. Fares F, Fardeau JC and Jaquin F (1983) Studies on synthesis and turn-over of organic bound phosphorus during incubation in different soil types. In: actes du ème Congrès International sur les composés phosphorés, pp. 593-590. IMPHOS, Casablanca, Maroc

20. Faurie G (1980) Devenir del'ammonium en sol calcaire: nitrification et volatilisation de l'ammoniac, $250 \mathrm{p}$. Thèse Doctorat d'Etat, Lyon

21. Finck A (1982) Fertilizers and fertilization, 438 p. Verlag edt

22. Fixen PE and Ludwick AE (1982) Residual available phosphorus in near neutral and alkaline soils: persistence and quantitative estimation. Soil Sci Soc Am J 46: 335-338

23. Fried $M$ and Dean LA (1952) A concept concerning the measurement of available soil nutrients. Soil Sci 73: 263-271

24. Frossard E (1985) Etude expérimentale de l'influence de composés organiques sur l'évolution des ions phosphate en sols ferrallitiques. Thèse, INPL, Nancy

25. Gachon L (1969) Les méthodes d'appréciation de la fertilité phosphorique des sols. Bull AFES 4: 17-34

26. Gachon L (1973) Vieillissement de divers engrais phosphatés en relation avec le type de sol etudié et la méthode Chang et Jackson. Ann Agron 24: 585-613 
27. Gachon L (1978) Utilité d'un bon niveau de réserves phosphatés du sol. Phosphore et Agri 70: $27-33$

28. Hagin $J$ and Shelly K (1985) Effectiveness of partially acidulated rock phosphate as a source to plants in calcareous soils. Fert Res 8: $117-127$

29. Halm BJ Stewart JWB and Halstead RL (1972) The phosphorus cycle in a native grassland ecosystem. In: Proceedings of a symposium Isotopes and Radiation in Soilplant Relationships Including Forestry, pp. 571-586. AIEA SM-151/7, Vienne

30. Jenkinson DS and Powlson DS (1976) The effects of biocidal treatments on metabolism in soil. I. Fumigation with chloroform. Soil Biol Biochem 8: 167-177

31. Jose AI and Krishnamoorthy KR (1972) Isotopic exchange of phosphate in soil: E value. Soils and Fertilizers 35: 620-627

32. Khasawneh FE and Doll EC (1978) The use of phosphate rock for direct application to soils. Adv Agron 30: 159-206

33. Kucey RMN and Bole JB (1984) Availability of phosphorus from 17 rock phosphates in moderatly and weakly acidic soils as determined by ${ }^{32} \mathrm{P}$ dilution, $\mathrm{A}$ value and total $\mathrm{P}$ uptake methods. Soil Sci 138: 180-188

34. Larsen S (1968) The influence of organic matter on loss of available phosphate in soil by chemical reaction. In: Symposium on Isotopes and Radiation in soil organic matter studies, pp. 377-381. AIEA SM-106/3, Vienne

35. Larsen S and Widdowson EA (1971) Ageing of phophate added to soil. J Soil Sci 22: 5-8

36. Larsen S (1967) Soil phosphorus. Adv Agron 19: 151-210

37. Larsen $S$ (1974) Food. Phosphorus: a limiting factor in future for food production. Neth J Agric Sci 22: 270-274

38. Marini P and Fardeau JC (1970) Evolution du superphosphate anciennement enterré; measure par échange isotopique. CR Acad Sci Paris, T 270, Série D, 3239-3242

39. Moody PW and Barry GA (1983) The use of buffer capacity and intensity factor for the assessment of phosphate status of soils. In: Actes du $3^{\text {ème }}$ Congrès International sur less composés phosphorés, pp. 209-215. IMPHOS, Casablanca, Maroc

40. Nye PH (1981) Changes of $\mathrm{pH}$ across the rizhosphère induced by roots. Plant and Soil 61 : $7-26$

41. Olsen SR, Cole CV, Watanabe FS and Dean LA (1954) Estimation of available phosphorus in soils with sodium bicarbonate. Circ ${ }^{\circ} 939$, Washington, USDA

42. Olsen SR and Watanabe FS (1957) A method to determine a phosphorus adsorption maximum of soils as measured by Langmuir isotherm. Soil Sci Soc Am J 21: 144-149.

43. Parfitt RL (1978) Anion adsorption by soils and soil materials. Adv Agron 30: 1-52

44. Probert ME and Larsen S (1972) The kinetics of heterogeneous isotopic exchange. J Soil Sci 23: $76-81$

45. Sauchelli V (1965) Phosphates in agriculture. New York: Reinhold Publishing Corporation

46. Sheppard CW (1972) Basic principles of the tracer method. Introduction to mathematical tracer kinetics. London: John Wiley \& Sons

47. Sibbesen E (1977) An investigation of the anion-exchange resin for soil phosphate extraction. Plant and Soil 50: 305-321

48. Warren RG (1956) N.P.K. residues from fertilizers and farmyard manure inlong term experiments at Rothamsted. Proc Fert Soc, $n^{\circ} 37,24 \mathrm{p}$

49. White RE and Beckett PHT (1964) Studies on the phosphate potentials of soils. Part I. The measurement of phosphate potential. Plant and Soil 20;1-16 